\title{
On the Way to High Level of Social Welfare: The Role of Motherhood in the Development of Productive and Entrepreneurial Activities
}

\author{
Diana Rakhmatullina \\ Institute of Management, Economics and Finance, Kazan \\ Federal University \\ Kazan, Russian Federation \\ na_nulya_@list.ru
}

\author{
Natalyia Larionova \\ Institute of Management, Economics and Finance, Kazan \\ Federal University \\ Kazan, Russian Federation \\ natasha-lari@mail.ru
}

\author{
Julia Varlamova \\ Institute of Management, Economics and Finance, Kazan Federal University \\ Kazan, Russian Federation \\ jillmc@yandex.ru
}

\begin{abstract}
This article provides a detailed analysis of how motherhood changes the behavior of economic agents-women and as a result increases the limits of opportunities and potentials of the whole society. Psychologists note that women with the birth of a child have significant transformations in their consciousness and system of needs. It forces them to reconsider their previous style of life they used to have before becoming a mother. Now they have less time but more obligations and the strongest argument to the effective activities - their child's life. Statistics show that many mothers change their occupation, profession, start their own business, enrich the range of their skills and abilities for their further application in productive activity and achieve better results and improve the well-being of their family. Therefore, the maternal instinct, the desire to give to the child the very best of every possible things plays the role of the catalyst for the development of skills, entrepreneurism and productivity.
\end{abstract}

Keywords: welfare, skills, entrepreneurism, consumption

\section{INTRODUCTION}

The welfare of the society is defined by its opportunities and potential. It is formed under the influence of many factors that have different nature and degree of impact. These factors affect the production, distribution, exchange and consumption of vital goods, determine the position of the natural and social environment where human needs are being satisfied.

The society is a plenty of all types of interaction and all forms of association of people (women and men). They act as producers and consumers and perform their economic activities in order to achieve maximum benefits in conditions of their existing restrictions and system of their needs.
Motherhood is a special role of a woman. With the birth of a child in a woman's life is undergoing significant transformation, changing the goal of life and ways of their realization, systems o believes, values and needs determined by the new motive to raise the child and provide his life with all vital and other important benefits, selection of which is determined by the level of production and economic development. Psychologists note that the phenomenon of motherhood is a special motivational and needful state of a woman, a kind of system of values, dynamically developing throughout the life.

These changes transform the economic (productive) activities as a source and the main way to satisfy the goals under the influence of the strongest psychological and social motives. If the system of values and needs changes, it will certainly be reflected in a consumer behavior as well.

Then, if motherhood changes the behavior of women as consumers and as producers, it certainly entails changes in a social welfare, usually stimulating its growth. Provided that we do not consider the deviant behavior of the mother in the relations with the child. You don't get a lot of those in the life, but it can be, conditioned by some factors of a different nature, main of which are psychological deviations. Mature woman who accepts and performs properly the duties of upbringing and ensuring the life and safety of the baby born to her in accordance with her natural desire and physiological instincts.

\section{LITERATURE REVIEW AND RESEARCH METHODS}

The problem of motherhood has always been studied by scientists of different scientific fields and specialties: 
Thrifty Housewives, the best time managers and organizers. Are not these qualities the main abilities for entrepreneurship? Their efficiency of the all available funds and time is much higher than before the birth of the child.

As a rule, motherhood is accompanied by a stop in professional activities caused by the necessity to care of a newborn. It takes all the time of the woman's life until the baby becomes self-sustained. And the main thing is that this stopping period helps woman in a completely new style and schedule of her life after becoming mother to compare the working style of life before the birth and to look at her past job "from the outside" and feel real satisfaction with it. The problem of a fixed tariff grid in the enterprise and the inability to increase the level of income, lack of free time and time for self-realization and self-development, which expands the prospects of personal achievements, and many other problems are often realized by a woman only at the time of this break. There is a reassessment of opportunities and concentration of attention on strongly grown real desires and needs, material and temporary, and necessity of their more qualitative embodiment. That is why, often after maternity leave, women change the sphere of employment and even organize their own business, starting to engage in activities that seem to give more opportunities to meet the immediate needs of the family and bring more pleasure to the woman.

It turns out that the provision of conditions for the development of entrepreneurship, social sphere, conditions for self-realization is the reverse side of the negative consequences of the new mother's professional life. The development of an economy based on the freedom of business activity, the potential of the system of control and improvement of the quality of goods and services, and many other factors create conditions for the growth of public welfare. And if we take into account that one of the criteria for assessing well-being and welfare is a sense of happiness, the birth of a child necessarily leads to its increase.

The impact of motherhood on the growth of social wellbeing and welfare is obvious not only in connection with demographic indicators, but also with changes in many other factors that determine the economic activity of households with children, its results and the level of the life satisfaction.

\section{DISCUSSION}

The large-scale social changes in a modern society and the transformation of its social and age structure and demographic problems cause interest in the phenomenon of motherhood and the wide scientific researches of its problems.

The theory of welfare is one of the most relevant areas of research. Well-being is a broad, capacious concept, which is a complex of the socio-economic phenomenon that combines and includes various characteristics of the levels, lifestyle and quality of life of the population.

Let us consider in detail how these phenomena can be interconnected in the economy. We will start with the analysis of the concept of welfare and its assessment. and satisfy the needs not only of the individual, but their child, are forcing them to look for more effective ways to use limited resources. Therefore, good mothers become 
of households and their members, including women mothers. We will focus on them and analyze what changes occur in the economic life of a woman with the birth of a child. Here should be considered and taken into account sociopsychological factors, transforming the value system and the model of women's behavior that will influence the formation and outcomes of economic relations with women.

The study of motherhood and maternal behavior has a long tradition. Many scientists have repeatedly stressed the importance of such research. Psychology, which combines the trends of both natural-scientific and humanitarian approaches, is at the epicenter of the problems of motherhood.

B. Burns in the Preface to the book "Different faces of motherhood" writes that in case to understand child development we should focus the early years, which are the most important for the individual growth of the child, and it is probably important to explore the mother. If we want to understand human development, then motherhood is certainly an important area of research [25]. Studies of domestic and foreign psychologists emphasize that the most significant qualitative changes in a woman's self-consciousness occur when she becomes a mother [26, 27, 28].

The phenomenon of motherhood includes a set of attitudes and values, emotional and sensual side, personal characteristics of the mother and much more. The determinants of parental behavior are both biological and social factors, and its importance is expanding and is no longer limited to the adaptation of offspring [29].

Motherhood is one of the social roles, the content of which is strongly influenced by social norms and values, says V. I. Brutman [5]. G. G. Filippova [30] considers motherhood as a psychosocial phenomenon: providing conditions for the development of the child, and as part of the personal sphere of women. Motherhood is considered not only as a condition for the development of the child, but also as a special needmotivational component of the psychology of women, which is formed throughout life. G. G. Filippova in the content of the maternal sphere there are three blocks:

- the requirement of an emotional block is a phased development of emotional contact with the child, the necessity for his protection and care of his needs in motherhood, resulting from the reflection by the mother of their experiences;

- the operational unit consisting of different care methods and the structure of communication relations with the child, having a specific emotional coloring, that gives some characteristics: caution, softness, care, etc., the specifics of vocalization and facial expressions;

- value-semantic block, including the attitude to the child as an independent value like the value of motherhood as a status of " mother".

One of the main features of the human maternal sphere, according to G. G. Filippova, is not a fixed evolutionary, but a life-forming filling of the value-semantic block, needs and ways to satisfy them.
All of the above parameters of welfare assessment depend on the ways of organization and results of economic activity 
The functions of the mother are quite complex and diverse and are to ensure emotional well-being, the development of attachment, attitude to the world, successful communication [31]. The semantic experience of motherhood, according to S. A. Miryunova and E. A. Teterleva, is a new formation in the sphere of self-consciousness of a woman who has assumed the parental role. Motherhood, being a qualitatively new situation of a woman's development, starts the process of integration of her own life tasks and the tasks of the child who entered her world [32].

The biological aspects of motherhood combine researches about the mother and the conditions she provides. They are considered as the organization of the physiological and incentive environment for the child well-growth [33]. The conclusion is that with the birth of a child, the mother assumes the obligation and responsibility to provide with the vital conditions and benefits for life the defenseless and helpless child. This leads to a quantitative increase in the needs and quality requirements for their implementation compared to the period before the birth of the child. At the same time, the possibilities of a woman with a child are reduced due to temporary disability and a decrease in the amount of time that a woman can devote to job.

The quantity of hours per week that women can spend at the work among mothers is slightly lower, but compared with Western situation this factor is insignificant for Russian women. The native country employers rarely go so far as to give the mother the opportunity to work part-time. This means that mothers have lower wages due to reduced productivity rather than fewer hours of work [34].

There are many research works which are performed by foreign scientists and based on analyzes of different countries statistics. It is proved that children have a negative impact on women's earnings. In some works [35] it is noted that the gap in earnings between mothers and non-mothers is more predominant share of income differences than between men and women. One of the authors [36] calls the loss of earnings in cause of the birth of children as "a tax on mothers." According to her estimates, in the United States during the life of this amount this tax is about $\$ 1$ million. for women with higher education.

According to other estimates [37], maternity reduces wages by $16 \%$. Such a high estimate is due to the fact that the authors did not control any important explanatory variables than the quantity of children. Mothers are more likely to have breaks in work experience than women without children and are more likely to work part - time, which affects the decline in their experience in the labor market [38]. Anderson in his work [39] also argues that because of toddlers require more care and attention than older children, their mothers are more tired at home and less productive at work. An important factor determining the low wages of mothers in the labor market is the particular industry where a woman is employed. A comparison of mothers and women without children, with the persistence of other factors (firm size, marital status, education), shows that mothers are more likely to be employed in industries with flexible work schedules, allowing to combine useful activities at home and in the labor market [40].
The research interest is a comparison of estimates of mothers' losses in the labor market. In particular the following main hypotheses are substantiated:

- women with children, on average, have less human capital than women without children;

- women with children have on average lower productivity; prefer employment in jobs requiring less responsibility and intensity of work;

- the differences in wages of mothers and not mothers occur due to the fact that the presence of children reinforces gender discrimination;

- some of the loss in earnings of working women mothers caused by territorial and settlement factors.

The analysis of the professional categories on women's earnings impact shows that in comparison with womenlegislators, top managers and officials, professional workers earn $43 \%$ lower, qualified production specialists - 63\%, office workers - $66 \%$, in the service sector - $80 \%$, artisans and craftsmen $-67 \%$, workers, specialists and technicians$65 \%$, unskilled workers-96\% [41].

Very negative is the fact that if the level of human capital of the mother is high it leads the significant loss in her earnings.

According to the works of Western scientists "the ideal worker" for the market is a person who works forty hours a week or more [42]. A woman can become such a worker only if she has no children [43]. In contrast to Western countries, in the last few years in our country there is a strengthening of the norm of compulsory motherhood for all women. The result of conflicting social demands is a forced lower positioning of mothers in the labor market compared to childless women, as well as with men. The discriminating positions of mothers in the labor market are also related to the fact that the ideal worker and the ideal mother, from the point of view of society, are almost opposite to each other [42]. Women on parental leave partially lose their qualifications $[35 ; 38]$. Women with young children are being pushed into areas of the labor market that do not require specialized knowledge and / or extensive work experience. On "maternal" workplaces there is no rigid schedule, a mode of work [44].

We have an economic agent (a woman-mother) with very limited resources and opportunities to increase them and a large quantity of needs with high demands for the quality of their satisfaction, due to a strong motive to ensure good living conditions and adaptation to them of the members of their household (children).

This situation encourages the search for the best use of available funds and resources and obtaining the best possible results of their application. It makes mothers better to:

- organize the production and consumption of goods by connecting all the necessary factors of production;

- to make decisions on the management of goods production and economic activities; 
These identified and many other economic consequences

- risk the money, time, labor, business reputation, because the activity in the market is associated with great uncertainty, and the result is not guaranteed;

- to be an innovator, that is, to introduce new technologies, new products, methods of organization of production and economic activity.

All these features of behavior coincide with the content of entrepreneurial actions and develop entrepreneurial abilities-a set of qualities, skills, opportunities of a person, allowing him to find and use the best combination of resources for the production of goods, make reasonable consistent decisions, create and apply innovations, take acceptable, justified risks for the successful achievement of goals. Every good mother can boast of them.

The birth of a child stimulates the development and manifestation of entrepreneurial abilities, develops them.

\section{CONCLUSION}

Psychologists note that women with the birth of a child have significant transformations in their consciousness and system of needs. It forces them to reconsider their previous style of life before they become mother. The maternal instinct, the desire to give to the child the very best of every possible thing plays the role of the catalyst for the development of skills and production:

1. The mother - producer. Statistics show that many mothers change their occupation, profession, start their own business, enrich the range of their skills and abilities for their further application in production activities and achieve better results and improve the well-being of their family.

Moms are the best time managers and organizers. Accordingly, it should be noted that motherhood contributes to the development of women's entrepreneurial ability.

2. The mother - consumer. There are significant changes in consumer behavior of the women who had just become a new mother. Needs increase in quantity (for themselves and for the children), and in requirements to quality of goods (all the best is for children). It stimulates the consumer market. In order to satisfy the growing demand with increased quality requirements, the production of goods must also be improved and expanded.

It can be concluded that as a consumer, the mother woman makes her choice in the new conditions of the system of needs and limitations of its capabilities. These conditions tend to be more complex than her previous conditions of consumer choice: needs have increased significantly, as well as requirements for them, due to psychological and social factors, and at the same time the opportunities to satisfy them have decreased. It is confirmed by research analyzes of the decline in income levels of women mothers. It is obvious that if nothing is changed in the way of life, the level of achievement of utility from consumption will not be very high. But the incentive to a better life for her and her child is very high, so a woman, mobilizing all her potential opportunities, as a rule, finds a variant of resource allocation that gives the maximum results. of motherhood lead to changes in social welfare, stimulating its growth.

\section{ACKNOWLEDGMENTS}

The reported study completed as part of project MK2702.2019.6 "Research on the intergenerational heritage of welfare: an empirical analysis of the factors of population socio-economic mobility".

\section{REFERENCES}

[1] Filippova, G. G. Psychology of motherhood (comparative psychological analysis): Diss. doctor. the course of studies. Sciences / G. G. Filippova. Moscow, 2000. 24 p.

[2] R. J. Mukhametrakhimov Forms of interaction between mother and baby // Questions of psychology. 1994. No. 6. Pp. 16-25.

[3] Kovalenko N. P. Psychological features and correction of emotional state of a woman during pregnancy and childbirth: dis. .Cand. the course of studies. sciences'. SPb., 1998. - 20 s.

[4] Dobryakov I. V. Perinatal psychology. - Peter. - 2015.

[5] Brutman V. I., Filippova G. G., Khamitova I. Yu. Dynamics of mental state of a woman during pregnancy and after childbirth/ / Questions of psychology. 2002. No. 1. Pp. 59-69.

[6] Varga A. Y. Structure and types of parental relations: dissertation ... candidate of psychological Sciences: 19.00.01. - Moscow, 1986. $-206 \mathrm{p}$.

[7] Khamitova I. Yu. Psychology of deviant motherhood: methodical manual / I. Yu. Khamitova; Department of family and youth policy of Moscow, Moscow humanitarian University. in-T.-Moscow: Moscow humanitarian University. in-t, 2008. - 67 p.

[8] Agnayeva E. M. the Image of the future child in a pregnant woman / Yearbook of the Russian psychological society: Materials of the 3rd Congress of psychologists. 2528 June 2003: Vol. 1. - SPb.: Publishing house of St. Petersburg. University press,2003.Pp. 2732.

[9] Leus T. V. Representation of a woman about herself as a mother before and after childbirth: autoref. .Cand. the course of studies. sciences'. Moscow, 2001. -19 PP.

[10] Chibisova M. Yu. the Phenomenon of motherhood and its reflection in the self-consciousness of a modern young woman abstract. dis. .Cand. the course of studies. sciences'. - M., 2003.-21 PP.

[11] S. S. Semenycheva towards motherhood modern women // Herald of SPbSU. Series 12. 2008. Issue 4.

[12] Domnina C. B. Social welfare in the modern economy / C. B. Domnina. - Samara: SGASU, 2005. - 190 p.

[13] Polyakov I. V. Adaptive bases of economic behavior of workers / I. V. Polyakov. - Saratov: Publishing house of SSU, 2004. - 176 p.

[14] Rimashevskaya N. M. National welfare. Methodology and methodology of the study / N. M. Rimashevskaya. - Moscow: Nauka, 1989. - 254 p.

[15] Rzhanitsyna L. S. Young families with children: who are they, how do they live, what do they want? // Sociological research. 2011. No. 3. Pp. 85-94.

[16] Problems of distribution and growth of national welfare. edited by E. M. Agababyan and E. H. Yakovlev. - Moscow: Nauka, 1979. $261 \mathrm{p}$.

[17] Bobkov V. Quality and standard of living of the population territorial section / V. Bobkov, V. Vasiliev, A. Gulyugina, E. Odintsova, M. Smirnov / / Economist. - 2008.- No. 1.- Pp. 39-45.

[18] Qualitative economic growth: prerequisites, factors, results: monograph; [ed. - Voronezh: Scientific book, 2011.-152 PP 

people / V. F. Mayer. - Moscow : Mysl', 1968. - 220 p.

[20] Tamoshina G. I. Social needs and human interests / G. I. Tamoshina, V. p. Voronin, E. V. Timoshkina / / Vestnik vgta. 2009. - No. 4. - Pp. 20-23.

[21] Y. Shishkov, the Level of poverty in the contemporary world : methodological disputes / Shishkov // DOE and MO. - 2006. - No. 1. - Pp. 3-14.

[22] Prokhorova O. V. Factors of growth of social welfare / / Questions of economy and management. - 2016. - No. 5.1. Pp. 133-136. URL https://moluch.ru/th/5/archive/44/1587/

[23] Nikitina Yu. V., Ryzhkova Yu. a. System of integral indicators of welfare of the population // Models, systems, networks in Economics, technology, nature and society. 2013. No. 2 (6). URL: https://cyberleninka.ru/article/n/sistema-integralnyh-pokazateleyblagosostoyaniya-naseleniya.

[24] R. Patel. The value of nothing. How to remake a market society and revise democracy. I. Yu. New York: Picador, 2012. - 288 p. a

[25] Berns B. The Different Faces of Motherhood. N. J.; L., 1988.
[26] Isupova O. G. Social meaning of motherhood in modern Russia. 2000. - No. 11. Pp. 98-107.

[27] Ovcharova R. V. Psychological support of parenthood. - M.: Publishing house Of the Institute of psychotherapy, 2003. -319 p.

[28] Filippova G. G. Motherhood and the main aspects of its research in psychology. Voprosy .psychologies. - 2001. - No. 2. Pp. 22-36.

[29] K. R. Makhmutova Motherhood as a psychological phenomenon] / / Vestnik of Udmurt University. Series «Philosophy. Psychology.

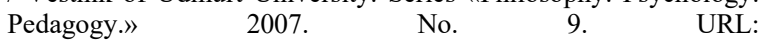
https://cyberleninka.ru/article/n/materinstvo-kak-psihologicheskiyfenomen.

[30] Filippova G. G. Motherhood and the main aspects of its research in psychology. psychologies. 2001. No. 2. Motherhood and general aspects of its studies in psychology

[31] Sirotenko D. I. Features of formation of psychological readiness for motherhood / / Innovative science. 2018. No. 9. URL: https://cyberleninka.ru/article/n/osobennosti-formirovaniyapsihologicheskoy-gotovnosti-k-materinstvu.

[32] Miryunova S. A., Teterleva E. A. Dialogical approach to the analysis of the semantic experience of motherhood. psychologies. 2003. No. 4.
Pyankova L. A., Khomicheva V. E. Psychological context of the motherhood phenomenon // Society: sociology, psychology, pedagogy. $2017 . \quad$ No. $3 . \quad$ URL: https://cyberleninka.ru/article/n/psihologicheskiy-kontekstfenomena-materinstva.

[34] L. I. Nivorozhkina, a.m. Nivorozhkin, S. V. Arzhenovsky Inequality in women's earnings: are children to blame? // Herald Of $\begin{array}{llll}\text { Tiuie. } 2007 . & \text { No. } & 2 . & \text { URL: }\end{array}$ https://cyberleninka.ru/article/n/neravenstvo-v-zarabotkahzhenschin-vinovaty-li-deti.

[35] Waldfogel, Jane. The Wage Effects of Children // American Sociological Review. 1997. 1 62. P. 209-217

[36] Ann Crittenden. The Price of Motherhood. New York: Henry Holt and Company, 2001.

[37] Anderson Deborah J., Melissa Binder, Kate Krause. The Motherhood Wage Penalty: Which Mother Pay It and Why? The American Economic Review. 2002. 192 (2). P. 354-358.

[38] Michelle J. Budig, Paula England. The Wage Penalty For Motherhood, American Sociological Review. 2001. 166 (2). P. 204-225.

[39] Anderson Deborah J., Melissa Binder, Kate Krause. The Motherhood Wage Penalty Revisited: Experience, Heterogeneity, Work Effort, and Work-Schedule Flexibility, Industrial LaborRelationsReview. 2003. 1 56(2). P. 273-294

[40] Jennifer Glass, Valerie Camarigg. Gender, Parenthood, and JobFamily Compatibility // American Journal of Sociology. 1992. P. 131-151.

[41] Arzhenovsky S. V., Artamonova D. V. Estimation of losses in wages of women with children. Applied econometrics. 2007. No. 3. URL: https://cyberleninka.ru/article/n/otsenka-poter-v-zarplatezhenschin-s-detmi.

[42] Ridgeway, Cecilia L., Shelley J. Correll. 2004. "Motherhood as a Status Characteristic"// Journal Of Social Issues. 2004. 60. no. 4. Pp. 683-700.

[43] F.J. Crosby, Williams J. C., Biernat M. 2004. "The maternal wall"// Journal of Social Issues. 2004. 60. P. 675-682

[44] Isupova O. G. Maternal career: children and labor strategies // Sociological research. 2015. No. 10. P. 195-204. 